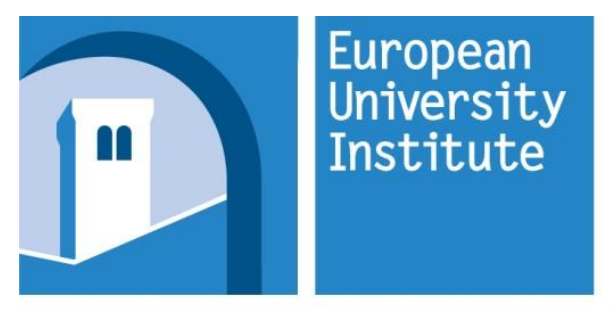

ROBERT

SCHUMAN

CENTRE FOR

ADVANCED

STUDIES
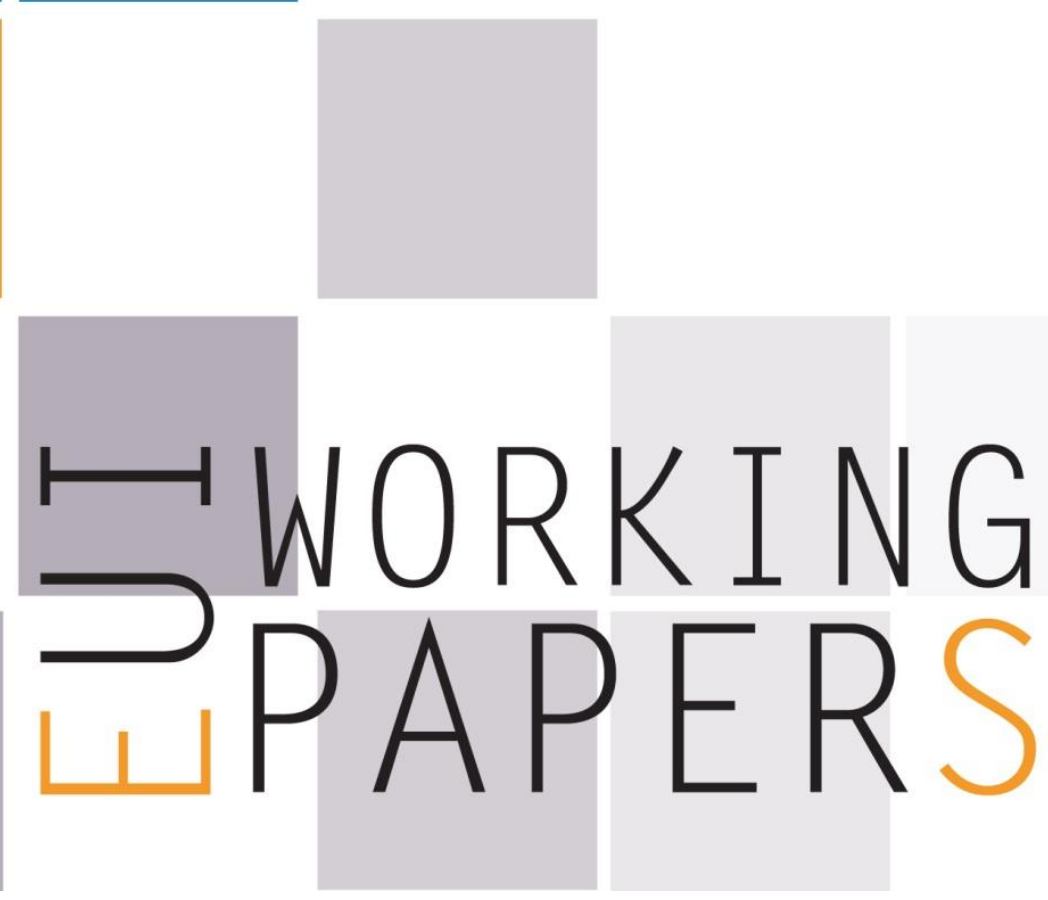

RSCAS 2014/115

Robert Schuman Centre for Advanced Studies Florence School of Regulation

\title{
Rail Transport: A Balance Sheet
}

Juan J. Montero 

European University Institute

Robert Schuman Centre for Advanced Studies

Florence School of Regulation

\section{Rail Transport: A Balance Sheet}

Juan J. Montero

EUI Working Paper RSCAS 2014/115 
This text may be downloaded only for personal research purposes. Additional reproduction for other purposes, whether in hard copies or electronically, requires the consent of the author(s), editor(s). If cited or quoted, reference should be made to the full name of the author(s), editor(s), the title, the working paper, or other series, the year and the publisher.

ISSN 1028-3625

(C) Juan J. Montero, 2014

Printed in Italy, December 2014

European University Institute

Badia Fiesolana

I - 50014 San Domenico di Fiesole (FI)

Italy

www.eui.eu/RSCAS/Publications/

www.eui.eu

cadmus.eui.eu 


\section{Robert Schuman Centre for Advanced Studies}

The Robert Schuman Centre for Advanced Studies (RSCAS), created in 1992 and directed by Brigid Laffan since September 2013, aims to develop inter-disciplinary and comparative research and to promote work on the major issues facing the process of integration and European society.

The Centre is home to a large post-doctoral programme and hosts major research programmes and projects, and a range of working groups and ad hoc initiatives. The research agenda is organised around a set of core themes and is continuously evolving, reflecting the changing agenda of European integration and the expanding membership of the European Union.

Details of the research of the Centre can be found on:

http://www.eui.eu/RSCAS/Research/

Research publications take the form of Working Papers, Policy Papers, Distinguished Lectures and books. Most of these are also available on the RSCAS website:

http://www.eui.eu/RSCAS/Publications/

The EUI and the RSCAS are not responsible for the opinion expressed by the author(s).

\section{Florence School of Regulation}

The Florence School of Regulation (FSR) is a partnership between the Robert Schuman Centre for Advanced Studies (RSCAS) at the European University Institute (EUI), the Council of the European Energy Regulators (CEER) and the Independent Regulators Group (IRG). Moreover, as part of the EUI, the FSR works closely with the European Commission.

The objectives of the FSR are to promote informed discussions on key policy issues, through workshops and seminars, to provide state-of-the-art training for practitioners (from European Commission, National Regulators and private companies), to produce analytical and empirical researches about regulated sectors, to network, and to exchange documents and ideas.

At present, its scope is focused on the regulation of Energy (electricity and gas markets), of Communications \& Media, and of Transport.

This series of working papers aims at disseminating the work of scholars and practitioners on current regulatory issues.

\section{For further information}

Florence School of Regulation Transport Area

Robert Schuman Centre for Advanced Studies

European University Institute

Via delle Fontanelle 19

I-50014 Fiesole (FI)

Tel.: +39055 4685795

Fax: +390554685755

E-mail: fsr.transport@eui.eu

Web:

www.eui.eu/DepartmentsAndCentres/RobertSchumanCentre/Research/Programmes/FlorenceSchoolR egulation.aspx 



\begin{abstract}
The creation of a single European railway area is the overall policy objective of the European Union for the railway industry. Rail infrastructure management is seen as a natural monopoly to be operated at a national scale. Competition is possible downstream in the provision of rail transport services. A European-wide market of rail transport services would benefit from larger economies of scale, and competition would ensure such efficiencies are passed down to European citizens and businesses. However, the reform process has been set back by Member States that disagree with the full vertical separation of infrastructure management and transport service provision, as well as by Member States that want to delay the full liberalization of the industry. As a consequence, inconsistent national models are emerging and non-sustainable asymmetries between Member States are creating tensions. The Fourth Railway Package is the opportunity to conclude the European railway reform process, both for commercial services and for public contract services. Imaginative solutions are necessary to reach a workable consensus.
\end{abstract}

\title{
Keywords
}

Railways, vertical separation, liberalization, public service obligations 



\section{The Single European Railway Area}

\section{A policy objective difficult to attain}

The creation of a single European railway area is the overall policy objective of the European Union for the railway industry. The single market objective is shared with other network industries: telecommunications (Single Digital Market), air transport (Single European Sky), energy (Internal Energy market), postal services, etc.

It is widely accepted that significant efficiencies can be reached if railway operations move from the national to the continental scale. Such a principle applies both to passenger and freight rail transport. Furthermore, environmental, security and road congestion reasons recommend promoting the growth of rail transport ${ }^{1}$ (Shift2Rail).

However, the application in the railway industry of the already established regulatory tool-kit for the reform of network industries is proving to be quite challenging. To start with, the national regulatory authorities have often lacked the required independence. Such independence is particularly relevant in the railway industry, due to the dominant influence of public undertakings in the industry and the need to separate the regulatory roles from the service provision roles. Access regulation has also been unevenly implemented. An agreement on the regulatory framework on public service obligations was reached with considerable difficulty (Regulation 1370/2007). ${ }^{2}$

Member States have been particularly reluctant to eliminate exclusive rights. ${ }^{3}$ A gradual approach allowed the liberalization, firstly, of the international groupings for international transport (1993), secondly, of international freight services (2006), thirdly, of national freight services (2007), and fourthly, of international passenger services (2010). Consecutive "packages" of legislation have advanced the liberalization process, at the expense of simplicity in the regulatory framework and legal certainty.

Moreover, numerous infringement procedures have been necessary to attain a minimum common denominator in the implementation of the railway packages across the Union ${ }^{4}$.

More than twenty years after the first attempts to open the market, the bulk of rail services in Europe are still provided under exclusive rights granted at a national level and mostly to the traditional public monopolies. Opposition to liberalization has not been limited to passenger services subject to public service obligations (in particular suburban and regional services). On the contrary, exclusive rights continue to be defended in several Member States for commercial services such as high-speed services.

1 European Commission (2011). Roadmap to a Single European Transport Area. Towards a competitive and resource efficient transport system, COM/2011/144.

2 Regulation (EC) No 1370/2007 of the European Parliament and of the Council, of 23 October 2007, on public passenger transport services by rail and by road and repealing Council Regulations (EEC) Nos 1191/69 and 1107/70, DOUE 31.12.2007.

3 Nash, C. A. (2008). Passenger railway reform in the last 20 years - European experience reconsidered. Research in Transport Economics, vol. 22, pp. 61-70; Gómez-Ibañez, J. \& De Rus, G. (2006). Competition in the Railway Industry. An International Comparative Analysis, Edward Elgar.

4 Versiluis, E. \& Tarr, E. (2013). "Improving Compliance with European Union Law via Agencies: The Case of the European Railway Agency”. Journal of Common Market Studies, vol. 51, issue 2, pp. 316-333. 


\section{Justification of the difficulties}

It should be understood, however, that solid reasons recommend a specific liberalization strategy for the rail industry. There are objective circumstances that differentiate the railway industry from other network industries.

The railway infrastructure is considered a natural monopoly and is declared as such in the Recast Directive. ${ }^{5}$ Competition has been excluded from the management of the rail infrastructure yet, at the same time, railway infrastructures require a very significant public investment. ${ }^{6}$

The provision of many rail transport services would not be competitive if the full cost of infrastructure would have to be included in the price of the transport service to the passenger. ${ }^{7}$ This is even more the case for freight transport services in Western Europe. As a consequence, it is not simple to define an objective pricing principle for access, such as the cost orientation principle imposed for regulated access in telecommunications or postal services.

A very significant proportion of passenger services have public service obligations. ${ }^{8}$ Compensation for public service obligations can reach a very substantial amount ${ }^{9}$. Exclusive rights are a proportionate compensation for such obligations. The scope of full competition is, therefore, substantially reduced. Competition in this segment can only be introduced as the so-called "competition for the market", that is, competition in the tender procedure to assign the public service obligation contract.

Other reasons do not seem so stand so solidly on the arguments put forward: The advantages of national integrated rail systems (infrastructure, transport services, rolling stock production, etc.), internal cross-subsidies in the public monopolies or national difficulties in implementing reform in rail companies, etc.

\section{Recent Achievements}

There have been some noteworthy achievements in the process of consolidating a single European rail market in the last five years.

Firstly, the institutional framework and market structure defined in the Railway Directives is finally taking shape, even though obstacles persist and harmonization is not as complete as necessary. A high number of infringement procedures initiated by the European Commission has been necessary.

Independent regulatory authorities have been established in the Member States, yet full independence is not universally guaranteed and not all the national regulatory authorities enjoy the necessary resources. However, the institutions have been established and formal independence granted. The next step is for these institutions to gather experience and to strengthen their position. Experiences such as the consolidation of transport regulators into a single entity (Italy) or the creation

5 Directive 2012/34/EU of the European Parliament and of the Council, of 21 November 2012, establishing a single European railway area, DOUE 14.12.2012, para. 71.

6 Subsidies to infrastructures summed 37 billion euros in EU-15 in 2005 according to European Environmental Agency 2007): Size, structure and distribution of transport subsidies in Europe, EEA Technical Report No 3/2007, p. 15.

7 Sanchez-Borràs, Nash, Abrantes \& Lopez-Pita (2010). Rail access charges and the competitiveness of high speed trains. Transport Policy, vol. 17, pp. 102-109.

8 Only three Member States have less than half of the total passenger/kilometers out of public service obligation schemes (Finland, France and Sweden), data in Commission Staff Working Document, Impact Assessment of the Fourth Railway Package, 2013, Annex 4, p. 4.

9 Subsidies amounted to around 20 billion euros in 2008 for the 27 member States. Commission Staff Working Document, Impact Assessment of the Fourth Railway Package, 2013, Annex III, page 47. 
of multi-network regulators (Germany, Netherlands and Spain) may be positive for the long-term maturity of the regulatory practice.

Some degree of vertical separation between network management and transport service provision has been ensured. Formal separation in different legal entities is quite common in the European Union. Some Member States ensure full separation, while other Member States, led by Germany, have developed a more restrained holding model. As explained below, this is one of the most relevant obstacles to completing the industry's reform process.

A formal procedure for path allocation and definition of access charges is taking place across the Union. Access regulation will be the main role of the national regulatory authorities and becoming the true cornerstone of the European single railway area.

At last, transparency has been introduced in the financing of public service obligations. Regulation $1370 / 2007$ is a complex piece of legislation and it challenges deep-rooted administrative practices in many of the Member States. However, the effort of the European Commission to define a coherent regulatory framework ${ }^{10}$ for the compensation of public service obligations across all industries is finally succeeding, also in the railway industry.

Secondly, Directive 2012/24/UE was adopted in November 2012. The Recast Directive simplified a significant part of the acquis communautaire on rail transport. It was definitely necessary after three legislative packages had introduced successive reforms in the original rail transport directives, some of them adopted as early as 1991. A more systematic legal regime dealing with the institutional framework, vertical separation, licensing, and network access was adopted.

Thirdly, in January 2013, after years of preparation, ${ }^{11}$ the Commission proposed the so-called Fourth Railway Package. If successful, it will complete the reform process of the European railway area. It includes three Directives and three Regulations.

An amendment of the Recast Directive is proposed ${ }^{12}$. It sets 2019 as the date for the full liberalization of national passenger services. It also reviews the institutional framework and the legal regime governing network access.

An amendment of Regulation 1370/2007 is proposed. ${ }^{13}$ The main novelties are: 1) the requirement of a transport plan to objectively justify imposing public service obligations; 2) the exclusion of direct assignment of public service obligations contracts to public companies. Competition for the market (tenders) will be introduced for the provision of national passenger services with costly public service obligations; and 3) ancillary provisions on caps for the contract volumes and on rolling stock availability.

10 Montero, Brokelmann, Menéndez, Cruz Ferrer, Franco \& Medina (2012). La financiación pública de las obligaciones de Servicio público. Tirant lo Blanch.

11 See for instance the studies commissioned by the European Commission: EVERIS (2010). Study on Regulatory Options on Further Market Opening in Rail Passenger Transport; and Steer Davies Gleave (2012). Study on further action at European level regarding market opening for domestic passenger transport and ensuring non-discriminatory access to rail infrastructure and services.

12 Proposal for a Directive of the European Parliament and of the Council amending Directive 2012/34/EU of the European Parliament and of the Council of 21 November 2012 establishing a single European railway area, as regards the opening of the market for domestic passenger transport services by rail and the governance of the railway infrastructure, $\operatorname{COM}(2013) 29$ final, 30.1.2013.

13 Proposal for a Regulation of the European Parliament and of the Council amending Regulation (EC) No 1370/2007 concerning the opening of the market for domestic passenger transport services by rail. $\operatorname{COM}(2013) 28,30.1 .2013$. 
A recast of the existing Directives on railway safety ${ }^{14}$ and interoperability ${ }^{15}$ is proposed to strengthen harmonization and interoperability. These are long-lasting objectives that will require the continuous support of the EU authorities, also in terms of financing. A new Regulation on the normalization of the accounts of railway undertakings is also proposed. ${ }^{16}$

Finally a new Regulation for the European Union Agency for Railways is proposed. The European regulator has as objective to facilitate market entrance of new operators and reduce administrative cost for railway undertakings.

\section{Remaining Challenges}

At this stage of the liberalization process, there are still different visions about the market structure in the European single railway area as well as about the final liberalization schedule, both for commercial services and for services with public service obligations.

\section{Vertical separation}

The structure of the market is still an open issue. ${ }^{17}$ Right from an early stage, the European Commission supported an orthodox vertical separation of activities. ${ }^{18}$ National monopolies with abundant public finance would manage the progressively harmonized rail infrastructure, a natural monopoly. Large transport service providers would reach a continental scale after the consolidation of the industry and they would be in the position to exhaust the inherent economies of scale. Competition between fewer continental players would ensure cost reductions are passed down to consumers, ensuring consumer welfare.

Some Member States, led by Germany, have always opposed a strict vertical separation. It is argued that such separation creates inefficiencies in the management of the national rail system. Furthermore, the larger efficiencies that could be delivered by the scale of the European single railway area will be delayed in time, due to the lack of interoperability of the national rail infrastructures. Germany and other Member States implemented a mere formal separation of their national operator, with both the network manager and transport service provider depending on a holding company.

The Court of Justice of the European Union, in a judgment delivered on February $28^{\text {th }}, 2013,{ }^{19}$ supported Germany's view that the Rail Directives do not really impose a strict vertical separation, but merely a legal separation. There are no shortcuts for the formal adoption of a clear legal obligation to

14 Proposal for a Directive of the European Parliament and of the Council on railway safety (Recast), COM(2013) 31 final, 30.1.2013.

15 Proposal for a Directive of the European Parliament and of the Council on the interoperability of the rail system within the European Union (Recast), COM(2013) 30 final, 30.1.2013.

16 Proposal for a Regulation of the European Parliament and of the Council repealing Regulation (EEC) No 1192/69 of the Council on common rules for the normalisation of the accounts of railway undertakings, $\operatorname{COM(2013)~} 26$ final, 30.1.2013.

17 Nash, C. A., Nilsson, J.E. \& Link, H. (2013). Comparing three models for introduction of competition into railways. Journal of Transport Economics and Policy, Vol. 47, Part 2, May 2013, pp. 191-206; and Van de Velde, Nash, Smith, Mizutani, Uranishi, \& Zschoche, (2012). Economic effects of Vertical Separation in the railway sector. Report to Community for European Railway and Infrastructure Companies.

18

Cantos Sánchez, P. (2001). Vertical relationships for the European railway industry. Transport Policy, vol.8, issue 2, pp. 77-83. Thompson L. (1997). The Benefits of Separating Rail Infrastructure from Operations, in The World Bank Group (Publ.): Public Policy for the Private Sector, Note No. 135, December 1997. A similar approach was adopted for the electricity and natural gas markets in Directives 2003/54/EC and 2009/73/EC., and for telecommunication networks in some countries such as the United Kingdom.

19 Judgment of the Court of Justice of the European Union of 18 February 2013, Case C-556/10, European Commission v. Federal Republic of Germany. 
be imposed on Member States to fully vertically separate the national rail systems, including economic separation $^{20}$.

The staus quo, in any case, is not sustainable. There is a clear asymmetry between the Member States that have already followed the Commission approach and those that decided not to do so. Actually, it is paradoxical situation that the rail company obtaining the largest benefits of the full vertical separation in other Member States is controlled by the Member State leading the opposition to the separation that ensures a level playing field.

Blockage could be overcome with a different approach to vertical separation. The Commission has proposed in the Fourth Package to allow Member States to close their networks to rail companies from Member States where strict vertical separation is not implemented. However, this approach is somehow contradictory with the Single Railway Area objectives, as it introduces barriers to market integration.

Another solution could be the adoption of a more demanding regulation on network access. The experience in the telecommunications industry, particularly in the sphere of landline telephone services, shows that access regulation can ensure very aggressive downstream competition despite the vertical integration of the network manager.

In any case, it seems clear that only by reaching a consensus on market structure will allow us to move onto the next debate on the full liberalization of the industry.

\section{Full liberalization of commercial services}

The Fourth Railway Package proposes 2019 as the date for the full liberalization of commercial national passenger services. The gradual opening of markets has the preferred approach of the European Commission. It has been the preferred option in the liberalization of telecommunications, postal services, etc. However, more than twenty years have passed since the initial timid initiatives for international groupings for international transport in 1993. It is indeed time to conclude the gradual reform of the industry.

Delays in the decision to fully liberalize the railway industry are generating inconsistencies and asymmetries. On the one hand, some Member States have decided to open their national markets to competition. However, the lack of harmonization is creating different models. The UK decided at an early stage to tender franchises for the provision of passenger services with exclusive rights. Full competition (so-called open access) was the option in Italy. The Spanish authorities have decided to grant special rights to new comers to create duopolies with the traditional public monopoly holder. The longer it takes to adopt the decision to fully liberalize, the greater the differences will be in the national models and ultimately, the more difficult will it be to harmonize the divergent national models.

On the other hand, some Member States have refused to introduce any reform not strictly mandated by the European authorities as is clearly the case of France. ${ }^{21}$ This is creating a very relevant asymmetry, as rail undertakings with solid exclusive rights in their home countries are benefitting from the possibility of expanding operations into Member States that have decided to pursue a liberalization policy. The asymmetry is triggering the introduction of both formal and informal reciprocity requirements, a situation clearly contrary to the notion of a single European railway area.

20 The CJEU confirmed the no binding legal value of Annex5 to the Communication on the implementation of the railway infrastructure package Directives, a mere Commission Staff working document that was never published in the official journal.

21

Quinet, E. (2006). France: Avoiding competition, in Gómez-Ibañez, J.A. \& de Rus, G. (editors): Competition in the railway industry: An international comparative analysis, Edward Elgar. 


\section{Competition for public service contracts}

The Fourth Railway Package proposes an amendment of Regulation 1370/2007 to eliminate the direct assignment to public rail companies of relevant public service contracts. Such a measure would significantly transform the provision of such services given that currently, most of them are directly assigned to the traditional national monopoly-holder. ${ }^{22}$

Interesting experiences exist in some member States. In the UK, the tendering of franchises model $^{23}$ is quite similar to the model proposed by the Commission. In Germany, tenders have been organized for some regional services. ${ }^{24}$ Other relevant experiences exist in countries such as Sweden, ${ }^{25}$ the Netherlands ${ }^{26}$ and Italy. ${ }^{27}$

The Commission proposes to reduce two of the identified barriers to entry to these tenders. Firstly, it proposes to reduce the volume of the contracts in terms of train-km, demanding either 10 million train-km or one third of the total national volume under public service contract. ${ }^{28}$ It has been identified in the German experience that large volume contracts are systematically assigned to the traditional railway undertaking.

Secondly, the barrier of entry of having access to rolling stock is reduced by imposing on Member States the obligation either to ensure the availability of rolling stock leasing companies, or to ensure that the residual value risk of the rolling stock is borne by the competent authority organizing the tender.

As a result, a single European railway area with European-wide rail undertakings competing for public service contracts could emerge. Costs for the provision of these services would thereby be reduced, for the benefit of both public authorities and EU citizens.

\section{Conclusion}

The European rail industry demands greater levels of certainty. A process of continuous review of the legislation does not benefit any of the players. The Fourth Railway Package should set the definitive regulatory framework for the next decade. There is an urgent need to complete a regulatory framework that 1) harmonizes the market structure in the different Member States, 2) takes into consideration the

22 See figures in Commission Staff Working Document, Impact Assessment of the Fourth Railway Package, 2013, Annex IV.

23 Preston, J. (2008). A Review of Passenger Rail Franchising in Britain: 1996/1997-2006/2007”. Research in Transportation Economics, vol. 22, issue 1, pp. 71-77.

24 Brenck A. \& Peter B. (2007). Experience with Competitive Tendering in Germany, Competitive Tendering of Rail Services, ECMT, pp. 139-161; Hunold, M., \& Wolf, C. (2013). Competitive Procurement Design: Evidence from Regional Passenger Railway Services in Germany, ZEW Center for European Economic Research Discussion Paper No 13-009, and a more critical approach in Link, H. \& Merkert, R. (2011). Success factors and pitfalls of the German rail franchising approach. International Journal of Transport Economics, XXXVIII(2), pp. 171-198.

25 Alexanderson G. \& Hulten S. (2007). Competitive Tendering of Regional and Interregional Rail Services in Sweden. Competitive Tendering of Rail Services, ECMT, pp. 165-187.

26 Van Dijk H. (2007). Tendering and Decentralization of Regional Rail Passenger Services in the Netherlands. Competitive Tendering of Rail Services, ECMT, pp. 127-137, and Van de Velde, Jacobs, \& Stefanski (2009). Development of Railway Contracting for the National Passenger Rail Services in the Netherlands, 11th Conference on Competition and Ownership in Land Passenger Transport.

27 Stanta, F. \& Galli, M. (2007). Local Railway Tenders in Italy: The Impossible Competition. 9th Conference on Competition and Ownership in Land Transport.

28 Article 2a.6.b) of the proposed Regulation, based on assessment in Commission Staff Working Document, Impact Assessment of the Fourth Railway Package, 2013, Annex VIII. 
special characteristics of the industry, and 3) allows European citizens to fully benefit from the European Railway Area.

\section{References}

Alexanderson G. \& Hulten S. (2007). Competitive Tendering of Regional and Interregional Rail Services in Sweden. Competitive Tendering of Rail Services, ECMT, pp. 165-187.

Brenck A. \& Peter B. (2007). Experience with Competitive Tendering in Germany, in Competitive Tendering of Rail Services, ECMT, pp. 139-161.

Cantos Sánchez, P. (2001). Vertical relationships for the European railway industry. Transport Policy, vol.8, issue 2, pp. 77-83.

European Commission (2011). Roadmap to a Single European Transport Area. Towards a competitive and resource efficient transport system, COM/2011/144.

European Environmental Agency (2007). Size, structure and distribution of transport subsidies in Europe, EEA Technical Report No 3/2007.

EVERIS (2010). Study on Regulatory Options on Further Market Opening in Rail Passenger Transport.

Steer Davies Gleave (2012). Study on further action at European level regarding market opening for domestic passenger transport and ensuring non-discriminatory access to rail infrastructure and services.

Gómez-Ibañez, J. \& De Rus, G. (2006): Competition in the Railway Industry. An International Comparative Analysis, Edward Elgar.

Hunold, M., \& Wolf, C. (2013). Competitive Procurement Design: Evidence from Regional Passenger Railway Services in Germany, ZEW Center for European Economic Research Discussion Paper No 13-009.

Link, H., Merkert, R. (2011). Success factors and pitfalls of the German rail franchising approach. International Journal of Transport Economics, XXXVIII(2), pp. 171-198.

Montero, Brokelmann, Menéndez, Deiana, Cruz Ferrer, Franco \& Medina (2012). La financiación pública de las obligaciones de Servicio público. Tirant lo Blanch.

Nash, C. A., Nilsson, J.E., Link, H. (2013). Comparing three models for introduction of competition into railways. Journal of Transport Economics and Policy, Vol. 47, Part 2, May 2013, pp. 191-206.

Nash, C.A. (2008). Passenger railway reform in the last 20 years - European experience reconsidered. Research in Transport Economics, vol. 22, pp. 61-70.

Preston, J. (2008). “A Review of Passenger Rail Franchising in Britain: 1996/1997-2006/2007”, in Research in Transportation Economics, vol. 22, issue 1, pp. 71-77.

Quinet, E. (2006). France: Avoiding competition, in Gómez-Ibañez, J.A. \& de Rus, G. (editors): Competition in the railway industry: An international comparative analysis, Edward Elgar.

Sanchez-Borràs, M., Nash, C., Abrantes, P., \& Lopez-Pita, A. (2010). Rail access charges and the competitiveness of high speed trains. Transport Policy, vol. 17, pp. 102-109.

Stanta, F. \& Galli, M. (2007). Local Railway Tenders in Italy: The Impossible Competition. 9th Conference on Competition and Ownership in Land Transport.

Thompson L. (1997). The Benefits of Separating Rail Infrastructure from Operations, The World Bank Group (Publ.): Public Policy for the Private Sector, Note No. 135, December 1997. 
Van de Velde, D. , Jacobs, J. \& Stefanski, M. (2009). Development of Railway Contracting for the National Passenger Rail Services in the Netherlands, 11th Conference on Competition and Ownership in Land Passenger Transport.

Van de Velde, Nash, Smith, Mizutani, Uranishi, \& Zschoche, (2012). Economic effects of Vertical Separation in the railway sector. Report to Community for European Railway and Infrastructure Companies.

Van Dijk H. (2007). Tendering and Decentralization of Regional Rail Passenger Services in the Netherlands. Competitive Tendering of Rail Services, ECMT, pp. 127-137.

Versiluis, E. \& Tarr, E. (2013). "Improving Compliance with European Union Law via Agencies: The Case of the European Railway Agency". Journal of Common Market Studies, vol. 51, issue 2, pp. 316-333. 
Author contact details:

\section{Juan José Montero}

Departamento de Derecho administrativo, UNED University

Calle Obispo Trejo, 2

28040 Madrid (SPAIN)

Email: jlmontero@der.uned.es 